\title{
Phalangeal and metatarsal bone destruction by subungual squamous cell carcinoma complicated by Peptostreptococcus sp. infection in a dog - importance of histopathological diagnosis
}

\author{
[Destruição óssea de falanges e metatarsos por carcinoma de células escamosas subungueal \\ complicada por infecção por Peptostreptococcus sp. em cão - \\ importância do diagnóstico histopatológico]
}

\section{"Relato de Caso/Case Report"}

\author{
Camila Barbosa Amaral ${ }^{1 *}$, Mário Antônio Pinto Romão², Ana Maria Reis Ferreira ${ }^{3}$
}

\author{
${ }^{1}$ Departamento de Medicina Veterinária, Faculdade de Medicina Veterinária, Universidade Federal do Espírito Santo, \\ Alegre-ES, Brasil. \\ ${ }^{2}$ Departamento de Patologia e Clínica Veterinária, Faculdade de Veterinária, Universidade Federal Fluminense, Niterói- \\ RJ, Brasil. \\ ${ }^{3}$ Programa de Pós-Graduação em Clínica e Reprodução Animal, Faculdade de Veterinária, Universidade Federal \\ Fluminense, Niterói-RJ, Brasil. \\ *Autor para correspondência/Corresponding author: E-mail: camilaosso@gmail.com
}

\begin{abstract}
The present article reports the case and complications of a canine with a subungual squamous cell carcinoma infected with Peptostreptococcus sp. whose initial diagnosis was erroneously considered as osteomyelitis, highlighting the importance of histopathological evaluation in digital lesions. A six-year-old female Rottweiler dog presented radiographic right metatarsal bone lysis after amputation of digit II phalanges due to a nonhealing ulcerated lesion. Amputated phalanges were fixed in formalin, but no histopathological evaluation was performed on that occasion. Osteomyelitis was suspected and clindamycin was prescribed. Bone lysis progressed up to tarsal bones even under antibiotic therapy, and due to its progression and severity, limb amputation was performed. Microbiological and histopathological evaluation of the limb respectively revealed Peptostreptococcus sp. and squamous cell carcinoma, the last one invading metatarsal bone, the same diagnosis later found in previously amputated phalanges. As shown on histopathological results, subungual squamous cell carcinoma advanced adjacent tissues and Peptostreptococcus sp. was considered an opportunistic agent. The patient recovered well and was healthy, with no evidence of metastasis a year and a half after amputation. The present case demonstrates the importance of histopathological evaluation to elucidate bone lesions and avoid complications, especially when digits are concerned.
\end{abstract}

Keywords: carcinoma; lysis; bacteria; digit; canine.

\section{Resumo}

O presente artigo visa relatar o caso e as complicações de um canino portador de carcinoma de células escamosas subungual infectado com Peptostreptococcus sp. cujo diagnóstico foi equivocado e inicialmente considerado como osteomielite, ressaltando-se a importância da avaliação histopatológica nas lesões de dígitos. Uma cadela da raça Rottweiler, com seis anos de idade apresentou imagem radiográfica de lise óssea em metatarsos após amputação das falanges do dígito II por lesão ulcerada não cicatrizante. As falanges amputadas foram fixadas em formol, mas a avaliação histopatológica não foi realizada na ocasião. Suspeitouse de osteomielite e prescreveu-se clindamicina. A lise óssea progrediu até o tarso mesmo sob antibioticoterapia e devido a severidade, optou-se pela amputação do membro. Exames microbiológicos e histopatológicos revelaram respectivamente Peptostreptococcus sp. e carcinoma de células escamosas, este invadindo os metatarsos, mesmo diagnóstico observado posteriormente nas falanges amputadas. Conforme observado no exame histopatológico, o carcinoma sub-ungueal avançou sobre os tecidos adjacentes e o Peptostreptococcus sp. foi considerado um agente oportunista. A paciente recuperou-se bem e permaneceu saudável, sem metástases, um ano e meio após a amputação. O presente caso demonstra a importância da 
avaliação histopatológica no esclarecimento de lesões ósseas de forma a se evitar complicações especialmente tratando-se de lesões de dígitos.

Palavras-chave: carcinoma; lise; bacteria; dígito; canino.

\section{Introdução}

Digital masses are relatively common lesions in dogs (O’Brien et al., 1992; Marino et al., 1995; Voges et al., 1996; Guerin et al., 1998; Wobeser et al., 2007; Belluco et al., 2013; Hauck, 2013). Around $80 \%$ of them are neoplasms and 60 to $70 \%$ are malignant (Marino et al., 1995; Wobeser et al., 2007). Squamous cell carcinoma is the most common subungual neoplasm in the dog (35 to $60 \%$ ), followed by melanoma, soft tissue sarcomas, and mast cell tumors (Liu and Hohn, 1968; O'Brien et al., 1992; Marino et al., 1995; Voges et al., 1996; Guerin et al., 1998; Henry et al., 2005; Wobeser et al., 2007; Hauck, 2013; Karayadi et al., 2013). Still, there are few subungual squamous cell carcinoma reports in veterinary medicine literature (Liu and Hohn, 1968; Henry et al., 2005). Clinical signs include digital swelling, pain, and ulceration (Liu and Hohn, 1968; O'Brien et al., 1992; Marino et al., 1995; Voges et al., 1996; Guerin et al., 1998; Henry et al., 2005; Wobeser et al., 2007; Hauck, 2013). Local nodes might be swollen (O’Brien et al., 1992; Guerin et al., 1998; Hauck, 2013). Radiographs of the affected digit must be part of the investigation since $80 \%$ of the subungual squamous cell carcinoma causes focal bone lysis while only 5\% (O'Brien et al., 1992; Marino et al., 1995; Voges et al., 1996; Wobeser et al., 2007; Hauck, 2013) to $40 \%$ (Guerin et al., 1998; Henry et al., 2005) of melanomas do. Subungual tumors are often secondarily infected and initially diagnosed as chronic paronychia or osteomyelitis, if only positive bacterial culture and radiographic images are considered. Histopathological evaluation is crucial to differentiate digital lesions and determine their etiology, especially when antibiotic therapy fails (O'Brien et al., 1992; Guerin et al., 1998; Hauck, 2013). This present case describes a dog with recurrent and invasive subungual squamous cell carcinoma and Peptostreptococcus sp. infection, initially diagnosed and treated as osteomyelitis, emphasizing the importance of histopathological diagnosis to avoid complications in treatment and clinical outcome of digital lesions.

\section{Description of the Case}

A six-year-old female Rottweiler was admitted at a private diagnostic center to perform right pelvic limb radiographs. Two months earlier, the patient had second and third phalanges of the digit II amputated due to a peri-ungual ulcerative non-healing lesion. The owner did not authorize histological evaluation on this occasion, but the specimen was kept in formalin solution. A few weeks later, the patient presented lameness and regional swelling of metatarsus and digits. At the amputation site, there were signs of chronic licking and a purulent and haemorrhagic exudate. There was mild popliteal lymphoadenomegalia. At that time, cephalexin (Rilexine ${ }^{\circledR}$ Virbac, $30 \mathrm{mg} / \mathrm{kg}$ BID) was prescribed due to clinical suspicion of osteomyelitis and radiographs of the right foot were requested. Radiographs showed metatarsal II bone lysis excepting the proximal epiphysis. Metatarsus III showed increased intramedular radiopacity and discrete cortical bone reaction. Radiographic alterations were suggestive of osteomyelitis. Clindamycin (Antirobe ${ }^{\circledR}$, Pfizer, 11 $\mathrm{mg} / \mathrm{kg}$ BID) and radiographic follow-up were indicated. No imaging alterations were observed after fifteen days. At day forty, the patient returned to the clinician with pain, non-weight bearing, purulent and haemorrhagic drainage, muscular atrophy and popliteal node swelling of the affected foot, apathy and weight loss, probably due to the owner's arbitrary suspension of the antibiotic. On this occasion, bone lysis was up to metatarsus III and IV and already compromising metatarsus V. Tarsal bone I, II, and III were absent, as was part of central tarsal bone and tarsus IV (Figure 1 and 2).

Due to this, previous amputated phalanges were analyzed and histopathological results revealed subungual squamous cell carcinoma. Considering the evolution of the bone destruction and absence of pulmonary metastasis, limb amputation was performed at the right hip joint. Purulent/haemorrhagic exudate was collected for microbiological culture and limb fragments to histopathological analysis. Microbiological culture was positive for Peptostreptococcus sp. 


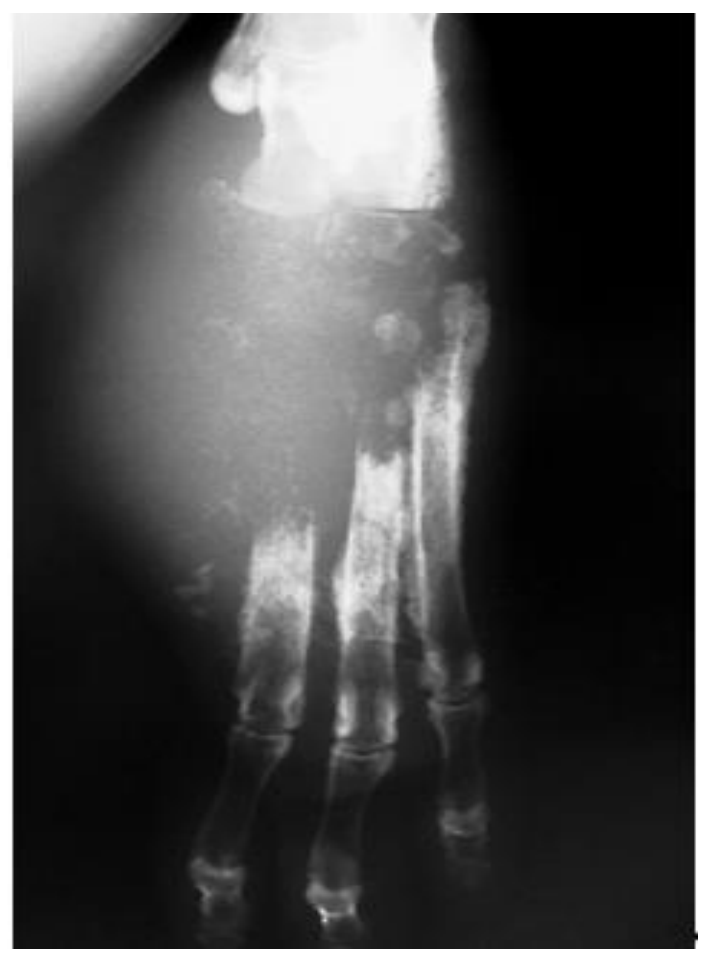

Figure 1. Right pelvic limb radiograph, dorsoplantar view: metatarsal bone lysis; increased radiopacity of the remaining diaphysis and absence of the distal tarsal row.

Histopathology revealed a squamous cell carcinoma with anaplastic epidermal cells, keratinized material disposed in concentric bundles, and inflammatory infiltrate. From the central tarsal bone, only a few bone fragments remained, invaded by neoplastic epidermal cells (Figure 3). Talus articular cartilage and

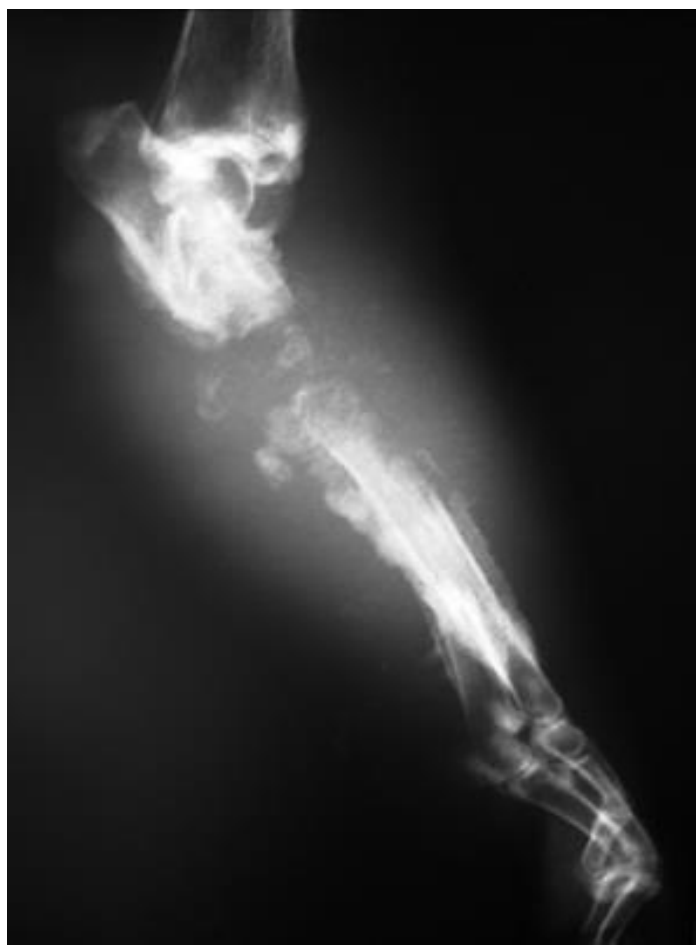

Figure 2. Right pelvic limb radiograph, mediallateral view: periosteal reaction on remaining metatarsal diaphysis. Compromise of the central tarsal bone and tarsus IV.

subchondral bone were intact, so was distal tibial epiphysis, but they were surrounded by neoplastic cells. Popliteal lymph node was reactive, but metastases were not seen. The dog recovered, welladapted to tripod support. Follow-up a year and a half later revealed no signs of metastasis.

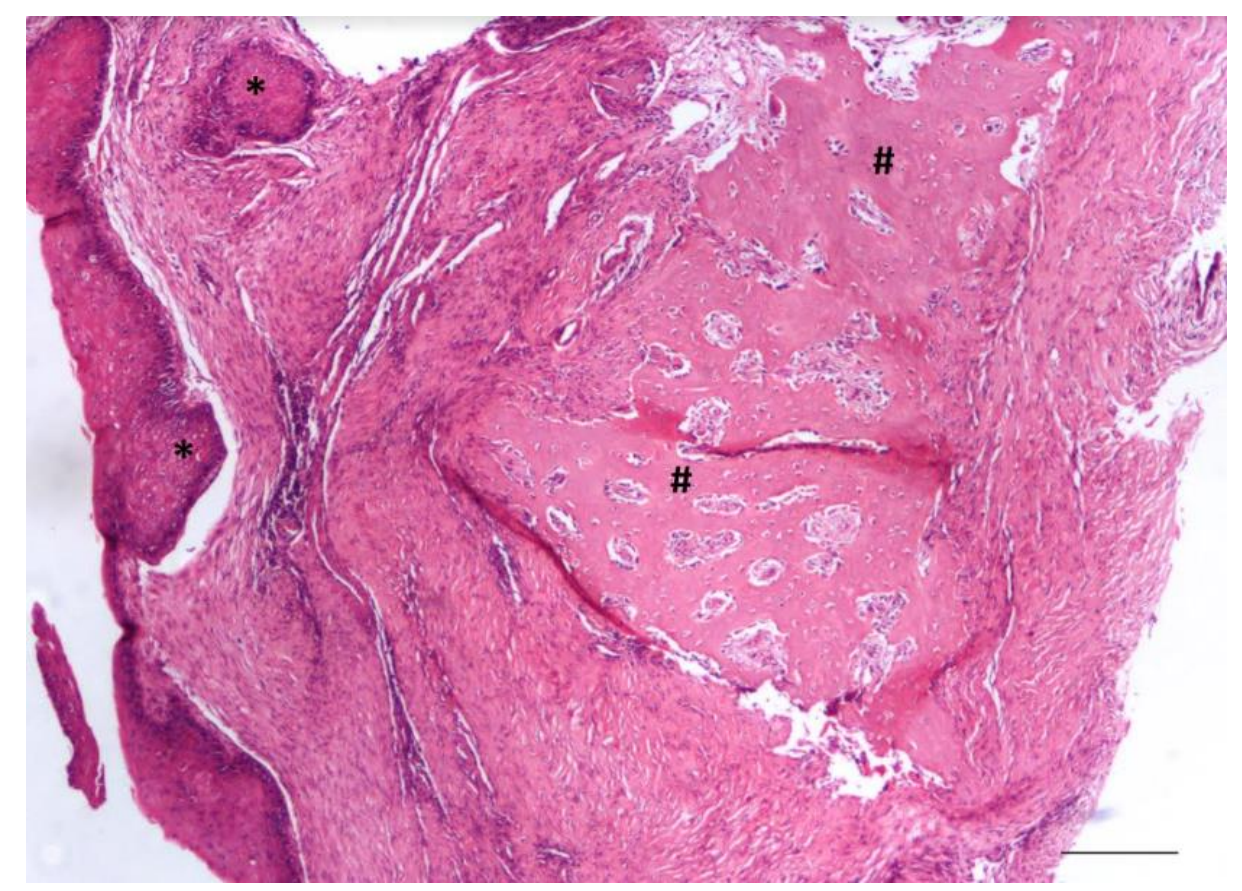

Figure 3. Photomicrography, right pelvic limb, squamous cell carcinoma: keratinized material and neoplastic cells $(*)$ surrounding and invading bone (\#). Bar $=200 \mu \mathrm{m}$. 


\section{Discussion}

Squamous cell carcinoma is a common neoplasm of domestic animals and man, with a variety of clinical forms affecting feet, face and abdomen more frequently (Paradis et al., 1989; Hauck, 2013; Karayadi et al., 2013). The subungual form of squamous cell carcinoma is locally invasive, causing distal phalangeal bone lysis in $80 \%$ of the cases (Liu and Hohn, 1968; O'Brien et al., 1992; Marino et al., 1995; Voges et al., 1996; Guerin et al., 1998; Henry et al., 2005; Hauck, 2013; Karayadi et al., 2013). Since benign lesions can also cause phalangeal lysis, histopathological diagnosis is crucial in distinguishing them among neoplasms (O'Brien et al., 1992; Marino et al., 1995; Voges et al., 1996; Guerin et al., 1998).

Subungual squamous cell carcinoma affects dogs around ten years of age without gender predilection (Paradis et al., 1989; Marino et al., 1995; Guerin et al., 1998; Henry et al., 2005; Belluco et al., 2013; Hauck, 2013). This patient was younger but in agreement with subungual squamous cell carcinoma occurrence in large dogs, especially those with primary black fur like Labrador Retriever, Rottweilers, Poodles, and standard Schnauzers (Liu and Hohn, 1968; Paradis et al., 1989; O’Brien et al., 1992; Guerin et al., 1998; Henry et al., 2005; Hauck, 2013; Karayadi et al., 2013). One recent study highlighted the role of altered KIT and MC1R genes in the oncogenesis of subungual squamous cell carcinoma in Standard Poodles of dark coat (Karayadi et al., 2013). This coat color can be a predisposing factor (O'Brien et al., 1992), opposing to what is observed in squamous cell carcinoma of the pina and nasal planum of dogs and cats with light or no skin pigmentation, where ultraviolet light plays a role in the induction of these tumors (Paradis et al., 1989; Lascelles et al., 2000; Hauck, 2013). Lesions show neither digital nor limb preference (O'Brien et al., 1992; Voges et al., 1996), although more recent studies reported forelimbs to be more affected than hindlimbs (Henry et al., 2005; Belluco et al., 2013). Masses are usually solitary, ulcerative, hemorrhagic, and expansive with fractured or absent nails (Liu and Hohn, 1968; Paradis et al., 1989; Guerin et al., 1998; Henry et al., 2005; Hauck, 2013). A similar description was reported for the initial lesion of the patient. Multiple lesions affecting different digits have been reported, whether for the same type of tumor or not (Paradis et al., 1989; Marino et al., 1995; Guerin et al., 1998; Henry et al., 2005; Belluco et al., 2013; Hauck, 2013).

Surgery has proven to be the only treatment modality to improve outcome, and local recurrence increases if amputation is conservative. Metacarpus/metatarsus-phalangeal or proximal interphalangeal joint disarticulation is recommended (Paradis et al., 1989; O'Brien et al., 1992; Guerin et al., 1998; Langley-Hobbs and Lascelles, 2004; Henry et al., 2005; Hauck, 2013) as initially performed in our patient. When more of the foot is compromised, limb amputation is recommended (Hauck, 2013), as was done afterwards.

However, even after digit amputation, the lesion progressed ascendantly. It is reported that up to one third of the subungual squamous cell carcinoma lesions can have local recurrence (O’Brien et al., 1992; Hauck, 2013). Possibly, in this case, adjacent tissues were already compromised with neoplastic cells at the time of amputation, as observed afterwards in tibio-tarsic histopathology. Invasion of adjacent bone is commonly observed histologically (Liu and Hohn, 1968; Guerin et al., 1998; Belluco et al., 2013).

The isolated bacteria did not seemed to be capable of causing the radiographic lesion considering observation of histopathologic slides and the fact the lesion progressed even under antibiotic therapy. Contaminated limb wounds in dogs and cats have the potential to cause osteomyelitis due to skin and bone proximity. Radiographic alterations commonly observed are lysis, periosteal formation and increased radiodensity (Walker et al., 1983; Langley-Hobbs and Lascelles, 2004), as seen on the first images of the patient.

Peptostreptococcus sp. is an exclusively anaerobic, gram positive coccus, usually present in the normal microbiota of the upper respiratory tract and low intestines, oral cavity, skin, and mucosae of humans and dogs (Price, 1991; Hodgin et al., 1992; Jang et al.,1997; Dahlén et al., 2012; Lawson et al., 2012; Davis et al., 2013). It has been isolated from subgingival plaques in dogs with gingivitis and periodontitis (Radice et al., 2006; Dahlén et al., 2012; Lawson et al., 2012; Davis et al., 2013) and in association with aerobic bacteria from osteomyelitis samples in dogs and horses (Walker et al., 1983; Hodgin et al., 1992). Positive results can be explained by constant licking of the non- 
healing wound, which served as means of entry for bacteria from the oral cavity in this case. It has been proposed that wound contamination can result from licking or contact with the ground, but it is not possible to confirm whether the isolated bacteria is representative of the infectious process or only a contaminant (Jang et al., 1997). Based on histopathological analysis of the amputated limb of the patient associated with lesion progression despite antibiotic use, there are two possibilities: first, it was only a contaminant or second, Peptostreptococcus sp. was potentiating the destruction caused by squamous cell carcinoma. However, the latter was the main cause of bone lysis and bacteria acted as a complicating factor, not a causative one, as evidenced by the very low bacterial cell count on the slides. Similarly, a previous study reported isolation of Streptococcus pyogenes in three dogs with squamous cell carcinoma of the digit, but without any significance attributed to bacteria on lesion development. Another important point in histopathology analysis is that evaluating the whole lesion, not only allows determination of the degree of differentiation, but also observation of the bone invasion by neoplastic epidermal cells, which might not be seen in cytology or small samples such as biopsy ones (Liu and Hohn, 1968).

Previous studies in dogs with subungual squamous cell carcinoma report metastasis rates of $3 \%$ in regional nodes and $20 \%$ in lungs (O'Brien et al., 1992; Belluco et al., 2013; Hauck, 2013), considering it of low metastatic potential. Dogs with a single affected digit and without metastasis do not require adjuvant therapy after surgery (O'Brien et al., 1992; Hauck, 2013), such as our patient at a first moment. Even so, the lesion progressed. In this case, tumor recurrence must have been related to adjacent tissue invasion by neoplastic cells but no pulmonary metastasis was detected previous to amputation and there was no popliteal node involvement afterwards. Subungual squamous cell carcinoma mean survival time is one and two years in $95 \%$ and $75 \%$ of the cases respectively (Marino et al., 1995; Hauck, 2013). Our patient was healthy, without metastasis a year and a half after limb amputation, regardless of the complications observed.

\section{Conclusion}

It was concluded that subungual squamous cell carcinoma has good prognosis but can present laborious diagnosis and treatment.
Histopathological confirmation is indispensable and must be associated with radiographic alterations found in digits, especially when clinical therapy fails. In this case, a suspicion of osteomyelitis was based only on radiographic images and therapy was ineffective because a neoplasm was the causative agent, and even though there was local recurrence, exeresis was successful with limb amputation.

\section{Conflict of Interest}

The authors declare no conflict of interest.

\section{Acknowledgments}

To Dra. Valeska Nogueira for sending the case and Dr. Frederico Ribeiro for performing the surgery.

\section{References}

Belluco, S.; Brisebard, E.; Watrelot, D.; Pillet, E.; Marchal, T.; Ponce, F. Digital squamous cell carcinoma in dogs: epidemiological, histological and immunohistochemical study. Veterinary Pathology, 50(6): 1078-1082, 2013.

Dahlén, G.; Charalampakis, G.; Abrahamsson, I.; Bengtsson, L.; Falsen, E. Predominant bacterial species in subgingival plaques in dogs. Journal of Periodontal Research, 47(3): 354-364, 2012.

Davis, I.J.; Wallis, C.; Deusch, O.; Colyer, A.; Milella, L.; Loman, N.; Harris, S. A crosssectional survey of bacterial species in plaque from client owned dogs with healthy gingiva, gingivitis and mild periodontitis. PLoS One, 8(12): e83158, 2013.

Guerin, S.R.; Jones, B.R.; Alley, M.R.; Broome, C. Multiple digital tumours in a Rottweiler. Journal of Small Animal Practice, 39(4): 200-202, 1998.

Hauck, M.L. Tumors of the skin and subcutaneous tissues. In: Withrow, S.J.; Vail, D.M.; Page, R.L. Withrow \& MacEwen's small animal clinical oncology. $5^{\text {th }}$ ed. Missouri: W.B. Saunders Company, 2013. p. 305-320.

Henry, C.J.; Brewer Jr, W.G.; Whitley, E.M.; Tyler, J.W.; Ogilvie, G.K.; Norris, A.; Fox, L.E.; Morrison, W.B.; Hammer, A.; Vail, D.M.; Berg, J. Canine digital tumors: a Veterinary Comparative Oncology Group retrospective study of 64 dogs. Journal of Veterinary Internal Medicine, 19(5): 720724, 2005. 
Hodgin, E.C.; Michaelson, F.; Howerth, E.W.; Austin, F.; Davis, F.; Haase, A.S. Anaerobic bacterial infections causing osteomyelitis/arthritis in a dog. Journal of the American Veterinary Medical Association, 201(6): 886-888, 1992.

Jang, S.S.; Breher, J.E.; Dabaco, L.A.; Dwight, C.H. Organisms isolated from dogs and cats with anaerobic infections and susceptibility to selected antimicrobial agents. Journal of the American Veterinary Medical Association, 210(11): 1610-1614, 1997.

Karayadi, D.M.; Karlins, E.; Decker, B.; vonHoldt, B.M.; Carpintero-Ramirez, G.; Parker, H.G.; Wayne, R.K.; Ostrander, E.A. A copy number variant at the KITLG locus likely confers risk of canine squamous cell carcinoma of the digit. PLoS Genetics, 9(3): e1003409, 2013.

Langley-Hobbs, S.J.; Lascelles, B.D. Phalangeal fractures and metacarpo-phalangeal luxations subsequent to post-traumatic osteomyelitis and cellulitis in a dog. Journal of Small Animal Practice, 45(7): 368-371, 2004.

Lascelles, B.D.; Parry, A.T.; Stidworthy, M.F.; Dobson, J.M.; White, R.A. Squamous cell carcinoma of the nasal planum in 17 dogs. Veterinary Record, 147(17): 473-476, 2000.

Lawson, P.A.; Johnson, C.N.; Bengtsson, L.; Charalampakis, G.; Dahlén, G.; Moore, E.; Falsen, E. Peptostreptococcus canis sp. nov., isolated from subgingival plaque from canine oral cavity. Anaerobe, 18(6): 597-601, 2012.

Liu, S.K.; Hohn, R.B. Squamous cell carcinoma of the digit of the dog. Journal of the American Veterinary Medical Association, 153(4): 411-424, 1968.

Marino, D.J.; Matthiesen, D.T.; Stefanacci, J.D.; Moroff, S.D. Evaluation of dogs with digit masses: 117 cases (1981-1991). Journal of the American Veterinary Medical Association, 207(6): 726-728, 1995.

O'Brien, M.G.; Berg, J.; Engler, S.J. Treatment by digital amputation of subungual squamous cell carcinoma in dogs: 21 cases (1987-1988). Journal of the American Veterinary Medical Association, 201(5): 759-761, 1992.

Paradis, M.; Scott, D.W.; Breton, L. Squamous cell carcinoma of the nail bed in three related giant schnauzers. Veterinary Record, 125(12): 322-324, 1989.

Price, P.M. Pyoderma caused by Peptostreptococcus tetradius in a pup. Journal of the American Veterinary Medical Association, 198(9): 1649-1650, 1991.

Radice, M.; Martino, P.A.; Reiter, A.M. Evaluation of subgingival bacteria in the $\operatorname{dog}$ and susceptibility to commonly used antibiotics. Journal of Veterinary Dentistry 23(4): 219224, 2006.

Voges, A.K.; Neuwirth, L.; Thompson, J.; Ackerman, N. Radiographic changes associated with digital, metacarpal and metatarsal tumors, and pododermatitis in the dog. Veterinary Radiology and Ultrasound, 37(5): 327-335, 1996.

Walker, R.D.; Richarson, D.C.; Bryant, M.J.; Draper, C.S. Anaerobic bacteria associated with osteomyelitis in domestic animals. Journal of the American Veterinary Medical Association, 182(8): 814-816, 1983. Wobeser, B.K.; Kidney, B.A.; Powers, B.E. Withrow, S.J.; Mayer, M.N.; Spinato, M.T.; Allen, A.L. Diagnosis and clinical outcomes associated with surgically amputated canine digits submitted to multiple veterinary diagnostic laboratories. Veterinary Pathology, 44(3): 355-361, 2007. 